\title{
THE SENIORS OF STOICISM OF EARLY GREEK (322-204 B. C.) AND THEIR ETHICAL PHILOSOPHY
}

\author{
Asst. Inst. Mohammad Abdul Kadim Jawad Al-Noori \\ The Ministry of Education
}

DOI: $10.37648 /$ ijrssh.v10i01.029

Received:07 ${ }^{\text {th }}$ October 2019; Accepted:26th November, 2019; Published: 07 ${ }^{\text {th }}$ December, 2019

\section{ABSTRACT}

Stoicism is a philosophical school of oriental origins, initiated in Greece in Helenste era after Alexander the Great's death (323-336 B. C.), which, in fact, deals with the human behaviour. This school has gained fame not less than what other Greek philosophical schools gained, but also its fame surpassed them, in which the effect and existence of its proponents have lasted for five centuries from the era of its founder the Cypriot Xenon in the late of the fourth century A. D. to the end of the Roman Emperor Marcus Aurelius(161-180 A.D.) reign in the late of the second century A. D.

The Stoic philosophy is distinguished from other Greek philosophies that preceded it to be a philosophy based on ethical and spiritual education. Its main job is the mental practice to the bases of ethical behaviour, and contains religious elements that the world is felt needed. Then, it is accepted by people, especially, the rulers that almost all of them become Stoic in the Roman Emperor Marcus Aurelius reign.

Key words: Stoicism, Xenon, ethics.

\section{INTRODUCTION}

The Stoic philosophy is considered as an important source for many ideas of religious philosophies, like Islam and Christianity, in which the views that it comes with causes a revolution in the history of philosophy in general, and the philosophy of ethics in particular. Those views do not last more than five centuries only, but they have the authority in intellectual environments, especially in Islam and Christianity. The followers of those religions believe that the philosophy does not mean that the human inspects the sky and earth with his eyes only, but it is a straight method in life and an industry to pursue the most appropriate way in the practical life, and the status of its message is its ability to guide people. The task of the philosopher is a mental-practical task, putting a side whatever transgresses mind whether this irrational thing is in the nature of universe or in human behaviour, and the aim is to push the followers of that doctrine to believe that the entire universe is guided by the public mind, and what exists in it does not deviate from the circle of the comprehensive system and that there are no marks for chaos and fortuity in existence.

\section{THE ESTABLISHMENT OF STOICISM AND ITS CHARACTERISTICS}

Stoicism is a philosophical school of oriental origins.It initiated in Greece in the Helenste era after Alexander the Great's death (336- 323 B. C.), responsive to the tense political, social and religious status. It is founded to meet a practical need before responding to the desire of theoretical knowledge, and to contribute in helping human being to resist in front of life conditions, that it is in fact a philosophy deals with human behaviour (Sa'ed,11). This school 
has gained fame not less than what other Greek philosophical schools have gained, but also its fame surpassed them, in which the other schools have broken down after the death of their founders. In spite of the criticism it faced this school has stayed strong and for a long time, that, the effect and existence of its proponents have lasted more than five centuries from the reign of its founder Xenon the Cypriot in the late of the fourth century B.C.to the end of the Roman Emperor Marcus Aureliusreign in the late of the second century A. D. (Ameen,8; Al-Nashar,125).

This philosophical school appeared about 307-306 B.C. (Al-Nashar,125), and was called Stoicism in reference to Pisianax Arcade, which is also called the Ornamented Arcade because of the ornamented pictures of the Greek painter Polygntos (lived in the early of the fifth century B.C.). People listened to Xenon the Cypriot, who tookIt as a venue for his school, so, he and his companions are called Stoics or the owners of arcade (Laertius,118-119).

Stoicism is not only a philosophical doctrine, but it is a combination of philosophy, religion, and ethics. This combination took Greek form, despite its oriental spirit. Even if it is found on Greek land, but it is not merely a fruit of the Greek thought, but a fruit of cultural communication between the east and west. This cultural convergence created an ease of transition between the Eastern and Greek countries. Thus, the intellectual crossfertilisation is a necessity imposed by circumstances (Al-Nashar,133). Then, the leaders of this school, especially the pioneers, are of oriental origins or their origins go back to Eastern cities (Ameen,6). This is confirmed by the historian Russell (392), who says "The first Stoics were Syrian in their dominant multitude".

Stoicism is a philosophy that contrasts the philosophy of Socrates (470-400 B.C.) and Plato (427-347 B.C.) and Aristotle (384-322 B.C.), in which they set their philosophies on the base of theoretical research before anything, but Stoics do not pay attention to theoretical views as much importance as the way for the practical side of life. Philosophy, according to them, does not mean investigating sky and earth with eyes and stop at that (Ameen\&Mahmood,281); Al-Khateeb,230), but it is, as Sinikya (4-65 B.C.) maintains, is a straight method in life and a science promises us to live in virtue and industry to pursue the most straight way in the practical life (Al-Nashar,201).

The Stoic philosophy is distinguished from other Greek philosophies that precede it to be a philosophy based on ethical and spiritual education, which it does not care much to scrutinize and respond to opinions, only to the extent that helped it to establish its rules and gave a strong and obvious picture to emphasize that the essential work of the school is a mental practice of the ethical behaviour that establishes other theoretical attitudes in the field of logic and knowledge, or in the field of nature (Abu Rayan,2014:221).

Despite this, practicality is a common feature between the Stoic school and other philosophical schools that precede it.What distinguishes it is that it stamps this practical purpose of its philosophy with a strong religious character. Stoics believed in the existence of God and the finality of the nature, and believed in the divine providence that is emanating in nature and beings (Al-Nashar,130). The Stoic school contained religious elements that the world is felt needed. The Greek appeared disable to provided the world in such a thing, then it is accepted by the common people, especially rulers, to the extent Gelbert Meri to say "Almost all the successors of Alexander announced, but we can say that all the major kings of the generations that came after Xenon had declared themselves Stoics (Russell,392), and this, certainly, meansthe spread of Stoic thoughts among people to the extent that almost all of them became Stoic in the reign of the Roman Emperor Marcus Aurelius (161180 A. D.) (Al-Nashar,131).

\section{THE EARLY SENIORS OF STOICISM}

\section{Xenon Al-Cittium (322- 264 B. C.)}

$\mathrm{He}$ is Xenon, Menacias or Dimias's son, born in (333 B. C.) in a Greek city resided by Phoenician settlers, which was called Kition (Laertius,115). His father is one of the Cypriot merchants, and he wasfrequented Athens for trade, and brought his son some books of the followers of Socrates, which once he read them, he admired the thoughts they bear, and from the earliest days, these books woke up in himself-conscious instinct and develop a passion for wisdom.He looked forward to contacting their owners (Florian,7-20)(Aweidah,71). The opportunity allows him to survived and reached 
Athens and settledin a bookstore after the sinking of his ship, which bore goods of Phoenician purple in the major port of Athens, Piraeus (Laertius:115-116). He reached Athens in 314 B. C. at the age of twenty two (Aweidah,72). Then, many philosophies educated him, like: " KratesAl-Kalbi, the founder of the cynicism, and ${ }^{* *}$ Astelon Al-Megari, as well as Aristotle's thoughts. After twenty years of frequenting on Greek schools, many field of philosophical doctrines are combined in his mind, so he began to select from each doctrine what he likes, and extracted a new philosophy with especial character (Ameen et. al.,279),( Kram,267).

Xenon lived a simple life, wearing cheap and simple clothes, content in a little bread, fig, honey, and a little win, and he rarely used slaves. He looked serious, and behaved like a sedate man, with a little talk, and preferred silence on talking, giving the reason that "We have one tongue and two ears to know that we should listened more than talked" (Laertius, 124-133); (Sa'id,57). He haslength of patience, willpower, self-control, chastity, and fancy control that astonished his contemporaries, so that he became a proverbial of the Athenians, that they say "More adjusted to the soul from Xenon" (Laertius, 135-136). Not only this, but they confessed his virtues and the impact of his philosophy in the upgrading of their city and stabilized the pillars of the government. At the age of ninety-eight in $264 \mathrm{~B}$. C., they officially lamented him. Their rulers issued a decision declaring that he deserved the nation's appreciation for his service and urge youth to virtue and wisdom, and therefore, honour him with a gold crown and a bronze statue in his life. They bury him in the burial of the grated after his death (Ameen,16); as do the same thing in his native city, because they consider his statue as a decoration crowns the brow of their city proudly, and in turn, the people of Kition

\footnotetext{
* Kratis Kalbi: is a native of the Greek city of Thebes, nicknamed (Thyrepanoiktes), ie the visitor who opens all doors, because of his belief in the entry of houses and advice to its people, and inherited from his father Escondas many money dispersed on the people of Thebes, (For details see: Laertus, Vol. 2, pp. 85-90)

**Astelon Al-Megari: From the Al-Megari school to the city of Megara, there is nothing left of his books and what is known about him scattered in the first two books (Hanafi, 1280. 1281).
}

in the city of Sidon are proud of his belonging to their city. The text of the decision to honour him reads:

"'As Xenon, Menacias's son, of Kition, devoted many years of his life to teach philosophy during his stay in our city, and as he was a virtuous man all his life in all things, and as he calls any youth frequenting his school for virtue and moderation, and urges them to do the best of deeds, and as presents them all a model to be followed because he fits and agrees with his words and deeds.So, the nation sawthat it would be better to praise Xenon, Menacias' son, and to crown his head with a gold crown, according to the law, due to his virtue and piousness, as well as to construct his grave in the district of the ceramics at the expense of the state, and the nation will be keen to vote to choose five men from the two ethnicities to carry out the crown work and the construction of the cemetery. The decision is to be engraved on two columns of alabaster, one at the Platonic school and the other at the Aristotelian school, and the needed money for all this work is delivered immediately to the interests of the state, so that all people know that the nation of Athens honours the heads of credit in their lives and after their death (Laertius,119-123); (Al-Nashar, 137-138).

Only titles remain from Xenon works, those are mentioned by the Greek historian Diogens La'ertus, which are: the republic, a letter about life according to nature, a letter about motives and human being nature, a letter about emotions, a letter about duty, a letter about law, a letter about Helenste education, a letter about sight, a letter about universe, a letter about signs, Pythagorean issues, a letter about wholeness, about style types, Homeric problems in five books, a letter about reading poetry, a booklet in eloquence, two books in refutation, the morality (Smith,125-126); (Sa'id,56; 117-118).

\section{Cleanthes (331-231 B. C.)}

$\mathrm{He}$ is the most famous of Xenon that he manages the school after likened as a hard resisted sheet to be written on, but severe retention to is written on (Laertius,243); (Al-nasher,:142).

Cleanthes, Phanias's son, was born in Asus, a city of small Asia in 331 B. C. It is said that he was a wrestler, and when he came to Athens, he has only four drachms. There, he met Xenon and learn philosophy from him. It is said that he was unable to bought papers for writing because of his poverty, so 
he wrote the lectures of Xenon on the shells of oysters and on the wide bones of oxen shoulders. His extreme poverty did not prevent him to continue his philosophical study.To paid the fees of learning, he worked at nights. He watered gardens, so, he was calledthe bearer of water from wells, as well as he worked to grind flour for one of the bakers. In the daytime, he trained himself on arguments and proofs (Laertius, 245-250); (Al-Nashar,142).

The historians' accounts mention that Cleanthes was differentiated by high qualities ofmettle and indomitable will. His extreme poverty and slow understanding, caused by his hard worked, did not prevent him to continue his study of philosophy that he can surpass his peers in maintaining instructions and retaining the high position of his teacher.Despite the difficulty Cleanthes encounters in the coalitions of opponents and to reply on their arguments, he haswit and ability to maintain his emotional state calm against his adversaries attacks, and ridicule skeptics of the supporters of Stoicism themselves in his abilities, in which they called him'donkey" (Ameen,:26); (ALNashar,143). He did not got angry because of this banter, but he replied 'he was indeed a donkey because he was the only able to carried the burden of Xenon school', (Laertius,247).

And among many students, Xenon admired Cleanthes virtues and his sedulity and seriousness in work, so he authorises him to succeed him to manage the school after his death (Sa'ed,58). Cleanthes stayed supervising the school's affairs for a long time from 264 to 232 B.C. (Ameen,26). He made an effort to retain the Stoic teachings, and for that, he argues violently the opposite doctrines for his philosophy that may weakened his authority and dispersed their followers (Al-Nashar,143); (Abu Rayan,222).

Only some extracts remained from Cleanthes accounts which reached about fifty books, most of them are about Xenon's natural philosophy and many classifications in logic and ethics (For more detail, see Laertius,250-251). The most important extract was a poem, which only forty verses remained of it.It apostrophizes the Greek god Zeus (a canticle for Zeus), and summarized the most important principles of nature and ethics in Stoic philosophy (Ameen,27-28).

Cleanthes died at the age of eighty, after being a student for his teacher Xenon for nineteen years. It is said that he died after suffering from a tumefaction in his gums, so, doctors prevented him from eating for two days. After healing and doctors allowance to resume his eating habits, he did not adhere to the orders and declared that he has passed a long journey of his life and continues his fast for the rest of his days until he died (Laertius,252).

\section{Chrysippos (282-206 B. C.)}

Cleanthes is succeeded by his student, Chrysippos (277-206 B. C.), in managing the Stoic school, who was regarded the last organiser and the setter of all parts of Stoicism, especially the method that he follows and his own way of proving. All of these things gave the final portrait of Stoicism (Bedewi,10). It is said that if it were not for Chrysippos, it would not have been possible for the Stoic school to exist after witnessing weakness and disintegration in the reign of Cleanthes (Ameen,3031).

Chrysippos, Apolones' son, was born in Soloi in Cyprus in 282 B. C. (Laertius,261). It is said that he was born between (277-281 B. C.) (Zeller,210). At that time, Cyprus was a place for political conflict between the leaders of Alexander the Great, that, the change of rulers and the conqueror leaders prohibited the prosperity of feeling of patriotism; therefore, it was not hard on Chrysippos to make the ideal in morality, the idea of mentalspiritual universality, which proclaims that the philosopher has no homeland, and the entire universe is his homeland (Ameen,1944:31).

Chrysippos was an athlete practises running for long distances (La'ertus,263). Then, he came to Athens and went to the philosophical school, because the wealth he inherited from his father was expropriated for the benefit of the royal treasury (AlNashar,150). He listened to Xenon, then, he became a student of Cleanthes, then, he left the school when the latter was alive. He has the opportunity to be eminent in the field of philosophy. He was a talented, intelligent person in all knowledge fields, in which he can argue with his teachers, Xenonand Cleanthes,over many issues (Laertius,263). He was accustomed to told his teacher, Cleanthes, that he needed only to decide the affair that neededto prove and he was sponsor to find this proof (Zeller,210); Al-Nashar, 149). 
It is mentioned that he has a great ability to philosophical argument, that, some said that if there was a chance to philosophical argument that the gods adopted method rather than Chrysippos' method (Laertius,263).

Also, it was mentioned that he was knowledgeable, and has many writings, in which he wrote about five hundred lines per day. He wrote almost more than seven hundred books in logic, physics, and ethics. Only excerpts of them remain. He was describedas aman who has a strong character that he does not follow the ways of his era's philosophers who preceded him in communicating and creating relationships with the kings and princes, that, none of his writtenwas presented to any of the kings in that era (Al-Nashar,150-151).

When Chrysippos undertook the administration of the Stoic school, his main concern was education, and managing the school well in a regular way. He made his mission with high mettle, without boredom. He made a great effort to defend Stoicism from the competitors and adversaries (Ameen,32). One of his positive opinions in philosophy that he distinguished between the first and second reasons was his theory that he succeeded via it to harmonize between the theory of destiny and the concept of responsibility, freedom, and morality.He said that inevitable destiny is the second reason, while our tendencies are the first one, in which they are under our control and we are free in directing them as we want (Ameen,35-36).

However, his adversaries nibble his redundancy in the theory of Stoicism about the thing that are neither good nor bad, like life, pleasure, and living. Also, they nibble his book "The Republic" that he permitted incest marriage, like the marriage of father and his daughter, the mother and her son, and the brother and sister. Also in his book "The Justice", he permitted people to be cannibals. In addition, they nibble his coarse style and impolite language, in which he did not use neat phrases and high style in his workedlike the authors of that time (Laertius, 2008:269-270).

Whatever the case, the rude style and impolite language used by Chrysippos, as well as the daring extremist views he declared, did not prevent others to confess favouring Stoicism. He remained loyal to Xenon's view regarding the basic issues, and it did not prohibit him to add some details and to illustrate what needed to be illustrated until Stoicism became a complete philosophy links clear parts because of his efforts (Ameen,39).

Chrysippos died at the age of seventy-three after a violent convulsion, and, reportedly, due to his excessive drinking of unmixed sweet wine (Laertius,266-267).

\section{THE PHILOSOPHY OF ETHICS IN EARLY STOIC SENIORS}

Stoicism is not a mere philosophical doctrine, but it is, in its heart, a moral doctrine.Morality occupies the first position, or in other words, it made from morality the target and fruit (Ameen,6). What refers to that is their definition for philosophy itself. They consider it as a practice of virtue, and the latter means to get rid of desire and to be free of excitement, Its head is wisdom, and from wisdom, the four essential virtues produced: clairvoyance, courage, chastity, and justice (Ameen,291).

Morality in Stoic philosophy relates to the human act according to the mind laws and his course according to the laws of nature, which means that there is a connection between nature and mind, and their motto is "live according to nature"' (Stees,282); (Abdul Ghani,12). Nature, which they mean to live according to, is our own nature as a part of the universe as a whole. It means that they believe in:

First:Ahuman is a natural creature.Then, he should be harmonized with this natural life that the natural world lives as a whole, containing creatures, especially the living creatures.

Second: man should live according to his own nature, which is a rational nature. What universal nature adds to human is mind and thinking, then, s/he should live according to his/ her rational nature, and makes whatever harmonizes with common universal mind, which is the great law that governs the world (AlNashar,203-204). Based on the concept above, we can say that the base of moral philosophy for the Stoic is to use mind in setting laws of human behaviour. With mind, A human lives in harmony with himself and with the entire world. The virtuous wise man, whose life goes on according to mind, lives according to nature, that, he is a real citizen of the world's citizens, accepts willingly whatever destiny brings, even disasters and calamities, 
believing that they enter the holistic system and divine fate. In contrast, one can find that the malicious man is always in conflict with himself and with existence. However, he rebels on destiny, there is no benefit because he cannot get rid of destiny, but destiny is what moves him whenever it wants (Ameen,160); (Badawi, 40).

What indicates the degree of individual perspective and comprehension for the laws of nature is his behaviour and deeds, not his sayings, Man does not have disobedience on the laws of existence, but as a rational creature, he is the only one who obeys these laws consciously and deliberately, and realising the desire of obtaining happiness (Karam,273).

But how is happiness obtained? Can manget it by his own power and possessions? Stoics treat this affair rationally, saying that happiness can be achieved into two ways:

First: to release self from rules of delusions by will.

They interpret this concept that man's happiness does not submit to the surrounding circumstances.But it depends on the state of oneself that is governed by will, in which the external things do not affect in itself on our internal being but the real impact is our psychological readiness that motivates us to live in such circumstances and judge it evaluating judgments, i.e. half of it good and half is bad. These judgments made for what relates to our life adapts our social circumstances, and make us feel either happy or miserable, comfortable or tired. Happiness, according to all of these, can be attained by anyone if he can release self from delusions of judgment. Abktitus" says about that "what affects people and their life is not things themselves, but their opinions about things. If Socrates looked for death as an evil because of horror in his heart, he did

Abktitus: (50-135 AD) Late Roman philosopher born in the city of Hierapolis in the province of Virgia, belongs to the Stoic school, was born a slave and the word (Epictetus) is not his real name, but is the title and means (person acquired) or slave, became a slave at the secret of Emperor Nero After discovering his talent, Abdu gave him a free education, and sent him to listen to the lectures of the Stoic philosopher Mosonius Rufus.He left nothing written, but his student Arianus narrated it in two books, Talks and the Manual (Papeete, Vol. 1, p. 94). * not regard death as an evil. He went toward it indifferent', It means that death is not a bad thing in itself as many people think, but the worst thing is to be afraid of it (Ottoman,161-162).

Second: the differentiation between the physical sense and the psychological attitude and this has a relation to his ability and will.

Their interpretation for this condition is that some see the generated emotions in oneself is something out of control and will or the rational rules, like gladness, pain, fear, sadness, etc. Although Stoics confess that the psychological emotions is a stumbling block in the happiness path, but they overcome this obstacle by differentiating between the physical sense that an individual cannot control and the psychological attitude that related to sense which has a relationship to his capability and will. One can feel pain and can endure it once, and once not, but he could decide freely whether he yields to this pain or not. And what is applicable to pain can be applied to sadness, fear and other emotions that influence human but his will prohibits it to move deep into the self. So, such emotions are wrong.Judgments should be fought in the name of happiness, mind, and nature, because nature needs our looking to it in a rational way, as mind illustrates that the events of universe is necessary because they submit to destiny (Abdah,56). The virtuous wise man is the one who "willingly accepts whatever the destiny brings, even disasters and calamities, believing that it is a part of the holistic system and divine destiny', (Ameen,159-160).

From the illustration above, it becomes obvious that Stoics emphasizes that happiness cannot be obtained without virtue that is known as (explicit mind), i.e. the perfect mind that always stays in harmony with itself, and the constant mind,which is the responsible for the human action (Al-Taweel,76). Virtue is based on will that yields to the mind rules.Each good and evil produced from its related to his will, and no one has authority over him, only in superficial things. To live in virtue, man should be wise, that, wisdom, according to Stoics, is the integrity of mind, and it is,in their philosophy, an art, of life, that not only guides man to what have to do specifically, but to what to do in general (Ameen,160-161; Ameen\&Mahmood,290-291).

Mind and wisdom make man lived in virtue, taking specific and constant way and attitude, while 
who walks far from mind and wisdom in his life has a changeable unsteady life. The wise man is the man who has all virtues at the same time, that, it is impossible to say that a man has a half virtue. Man is either to be wise and virtuous or to be impertinent deficient, in which who gains one virtue, gains the others, and who has one vice, has the others, because the explicit mind is the perfect one. It is either to be found as a whole or never be found basically. Related to this concept, Cleanthes states that " all people tend naturally to virtue, but who do not develop this tendency in themselves are devils, and who promote it are virtuous and good"' (Abu Rayan,235).

According to Stoics, the unity of virtue is like the unity of the self, As the selfappears to be as one united entity despite its various functions, virtue also appears as one unity and its purpose stay constant in spite of the change of its practices. It is like an eye that looks first to white and then to black. In other words, it is like eyesight that remains fixed; however the recognised things are varied (Sa'ed,1999:52).

One of the moral principles that Stoics believe in is the sympathy with the external nature and mankind regardless of their colours and nations. Living according to nature requires, necessarily, the belief in equality between mankind and not to discriminate their colour and sex (Al-Nashar,213). Thus, they infringe all the Greek traditions that discriminate between Greek and barbarians, the gentlefolks and common people, freemen and slaves, and rich and poor. The only difference between people in Stoicism is the difference between virtuous and foolish. They look at all people as brothers belong to what differentiate them from animals, that, all people are like one body and submit to one natural law which moves them to one destiny (Abdul Hay,298-299). Also, the concept of natural law regards man, necessarily, as part of the universe, in which he is created to play his role in this natural world like other creatures, so he has to be sincere in his duty (Al-Nashar,213); (Badawi,50).

In addition, Stoics emphasize, in their moral philosophy, the principle of internationality. Humanity, according to them, goes beyond settings. It is similar to a family, its members are all human beings regardless of their languages and countries, so, they are different from Plato and Aristotle, who know only friendship and sympathy among the citizens of people of one city (Ameen,172). Aristotle sees that the Greeks are only theoldest and most valuable people than those who are not Greeks (Aristotle,5).

And the universality of humanity that Stoics call for is based on the existence of tight moral relationships between gods and mankind. They believe that the human soul does not differ from the mind of universe and gods and mankind are in reality parts of this universal mind. And when human is a creature built by nature to prosperity. People have to be brothers and to accustom each other, which Stoics call it the realm of mind, which contains all people regarding them to get the same share of mind and they are ready for virtue. Thus, the ideal state, according to Stoics, do not have limits or differences, but it is a rational society contains all people, but it is a wide idealempire (Ameen,173).

In other words, all people are brothers, and you, man, if you are sane, you have to love your neighbour and respect others. The neighbour, in the dictionary of Stoicism, is not the geographical neighbour- the national specifically, or the political, lingual, racial, class, or communal.It is the moralrational neighbour. It is any man and each man, so, the concept of universal love bears in its heart the ethical philosophy of Xenon that causes a revolution in the history of philosophy in general, and in philosophy of ethics in particular (Abud,2008).

In sum, it becomes clear that Stoicism, in its core, is a philosophical doctrine. Morality occupies the first position, and its followers like the speech that leads to actions, and believe that the status of its message is its ability to be a guide to people. The task of the philosopher is a mental-practical task, putting a side whatever transgresses mind, whether this irrational thing is in the nature of universe or in human behaviour. It is regarded by people as a leader and a guide for their conscience, and the aim is to push the followers of that doctrine to believe that the entire universe is guided by the public mind, and what exists in it does not deviate from the circle of the comprehensive system and there are no marks for chaos and fortuity in existence.

\section{CONCLUSIONS}

- Stoicism is a philosophical school of oriental origins, initiated in Greece in Helenste era after Alexander the Great's death. 
- This school gained fame not less than what other Greek philosophical schools gained, but, also, its fame surpass them because it contains religious elements that the world felt needed. Then, the effect and existence of its proponents have lasted for five centuries from the era of its founder the Cypriot Xenon in the late of the fourth century A. D. to the end of the Roman Emperor Marcus Aurelius reign (160-181 A. D.) in the second century A. D.

- The Stoic philosophy is distinguished from other Greek philosophies that preceded it to be a philosophy based on ethical and spiritual education. In fact, philosophy calls for using mind in setting laws of human behaviour, and emphasizes that happiness cannot be obtained without virtue that based on will that submits also to the rules of mind. To live in virtue, man should be wise, that, wisdom, according to Stoics, is the integrity of mind. Mind and wisdom make man lived in virtue, taking specific and constant way and attitude. The wise man is the man who has all virtues at the same time.

- Stoics emphasize in their moral philosophy the principle of internationality. Humanity, according to them, is akin to a family that its members are all human beings regardless their languages and countries. Also, they emphasize the universality of humanity that Stoics call for. It is based on the saying which assumes that human's soul does not differ from the mind of the universe, and since human is a creature built by nature to prosperity, sopeople have to be brothers and to accustom each other, which Stoics call it the realm of mind, which contains all people regarding them to get the same share of mind and they are ready for virtue. Thus, the ideal state, according to Stoics, does not have limits or differences, but it is a rational society contains all people, but it is a wide ideal empire.

\section{REFERENCES}

Abood, A. (2008). Stoicism, an international philosophy. http//www.Jableh.info.
Abdah, M. (1999). Ethics philosophy. (2 ${ }^{\text {nd }}$ Ed.). Qairo: Madboli library.

Abdul Ghani, M. (1994). About the philosophy of nature at Stoics. Qairo: Dar Al- Thaqafa for publication.

Abdul Hay, O. (2006). The political thought in ancient eras. ( $2^{\text {nd }}$ Ed.). Beirut.

Abu Rayan, M. (2014). The history of philosophical thought, Aristotle and the late schools. Egypt:Dar Al-Wafa'a press.

Al-Khateeb, M. (1999). The Greek though. Damascus: Dar Ala'a Al-Deen.

Al-Nashar, M. (2013). The history of Greek philosophy from oriental perspective: the Greek philosophical schools in Helenste era. Qairo: Al-Dar Al Misryah AlLubnanya.

Al-Taweel, T. (1960). The creation philosophy, its creation and development. Qairo.

Ameen, Z. \& Mahmood, Z. (1935). The story of the Greek philosophy. Qairo:Dar Al-Kutub AlMisriah.

Ameen, O. (1944). Stoic Philosophy. Qairo: The publication, translation and authorship committee press.

Aristotle. (1957). The policies. Translated by Augustus Barbara Al-Bolesi. Beirut.

Babeti, A. (2009). The encyclopaedia of famous Arab, Muslims and international. Dar AlKutob Al-Elmia.

Badawi, A. (1979). The autumn of Greek thought. $\left(5^{\text {th }}\right.$ Ed.). Qairo: Al-Nahda Al-Misryah library.

Florian, C. (1920). The Purpose of Zeno's Arguments on Motion.

Hanafi, A. (1999). The encyclopaedia of philosophy and philosophers. (2 ${ }^{\text {nd }}$ Ed.). Qairo: AlMadboli library.

Karam, Y. (2012). The history of Greek Philosophy. Egypt: the organisation of Al-Hindawi for publication. 
La'ertus, D. (2008). Famous philosophers' life. Translated by: Emam A. Emam. Reviewed by: Mohammad H. Ibrahim. Qairo: the national centre for translation.

Russell, B. (2010). The history of the western philosophy. Translated by Zaki N. Mahmood. Reviewes by Ahmed Ameen. Qairo: Egyptian General Book Authority.

Stees, W. (1984). The history of the Greek philosophy. Translated by Mujahid Abdul Mun'em. Qairo: Dar Al-Thakafa for publication.

Sa'ed, J. (1999). The philosophy of Stoicism, study and selections. The university publishing centre.

Smith, W. (1870). Parmenides. Dictionary of Greek and Roman Biography and Mythology.

Zeller. E. (1980). Outlines of the history of Greek philosophy. (13 ${ }^{\text {th }}$ Ed.). Translated by .L.R.Palmer. New York: Dover publication Inc. 